\title{
Leaf Anatomical Modification in Drought of Rice Varieties (Oryza sativa L.)
}

\author{
Anggara Dwi Putra Zagoto, Violita Violita* \\ Department of Biology, Faculty of Mathematics and Science (FMIPA), Universitas \\ Negeri Padang. Indonesia \\ violitavioviolita@gmail.com
}

\begin{abstract}
Each organ plant has been formed perfectly to support physiological processes in an unfavorable environmental condition. Rice (Oryza sativa L.) be included plants sensitive to drought conditions during a stage of growth and development. This will cause pressure (stress) resulting in a decrease in rate metabolism in leaf cells. Leaf anatomical characteristics are criteria that can be used to identify plants that are tolerant to drought. Anatomical response leaves in drought conditions inform the development of leaf photosynthetic parts carrying out changes in anatomical structure morphology includes changes in cell walls, organ size, changes in direction growth, including dropping leaves and enhancing the life cycle. The research aimed to determine the anatomic response leaves rice varieties (Oryza sativa L.) to drought stress. Five rice varieties used were given drought-stress treatment for 12 days. Identification leaf anatomical structures using microscopic slices of transverse was made according to the paraffin method. Changes in the anatomical structure of leaves of drought-stress have decreased bulliform cells increase in size, the thickness epidermis cells in an effort to retain the water content in cells, and reducing the size and total stomata with purpose process control flow of transpiration and water use efficiency.
\end{abstract}

Keywords: Drought-stress, leaf anatomy, modification, physiology, rice (Oryza sativa L.)

\section{Introduction}

Drought is an environmental factor causes water not available to plants, which can be caused among others unavailability water in the area plant roots and large water demand in leaf area where the rate evapotranspiration water absorption plant roots [1]. Rice (Oryza sativa L.) be included plants sensitive to drought conditions during a stage of growth and development. Water shortage will interfere with many cellular functions in plants and negatively impact the growth and reproduction response rice plants confront drought-dependent severity of time growing phase occurrence drought [2].

Rice in the drought has shown symptoms of leaves rolling and drying. This symptom identifies leaves are unable to perform metabolic activity normally, unable to absorb nutrients and retarded formation chlorophyll leaves [3]. The ability of plants adapt to drought conditions is maintaining a pressure of turgor in potential conditions low tissue water, osmotic adjustments such as accumulation ascorbic acid [4] and tolerance of dehydration through protoplasm [5]. 
One organ in plants plays a role in controlling the physiological process in leaves. Leaf anatomical structure shows plants response to environmental factors such as light, moisture, temperature and $\mathrm{CO}_{2}$ through the development of photosynthetic parts leaf [6;7]

Anatomical structures related to the environment such as cuticle, hypodermis and epidermis derivatives show the identity of plant adaptation to environment [8;9]. The condition water deficit causes closure stomata to affect dehydration of leaf mesophile cells causing damage to photosynthesis organs [10]. To get drought-tolerant rice then important to observe an anatomical modification in a drought of rice varieties.

\section{Methods}

Research conducted at Wirehouse Department of Biology, Plant Structure and Development Laboratory, Universitas Andalas, Laboratory Tirtosari Malang, Laboratory Plant Physiology, and Integrated Research Laboratory, Faculty of Mathematics and Natural Sciences, Universitas Negeri Padang. The research design used was completely randomized design (CRD) factorial. The first factor is based on the ability rice varieties sprouts against granting a solution Polyethylene glycol (PEG) 8000 [11] and drought sensitivity index (DSI) value [12] consists five varieties (Table 1) and the second factor is drought which consists of drought without (control) and drought.

Table 1. Rice Varieties (Oryza sativa L.) based on Drought Sensitivity Index (DSI) Value.

\begin{tabular}{clllc}
\hline Code & \multicolumn{1}{c}{ Variety Name } & \multicolumn{1}{c}{ Origin } & DSI & Information \\
\hline V2 & Situbagendit & Pariaman & 0.93 & Moderate \\
V10 & Indragiri & Pasaman & 1.74 & Sensitive \\
V12 & Sijunjuang & Sijunjuang & 1.22 & Sensitive \\
V13 & Baroto & Sicincin & $-0,31$ & Tolerant \\
V14 & Randam Kaus & Batusangkar & 0.87 & Moderate \\
\hline
\end{tabular}

The seeds (each variety) were selected and continued sterilization using $20 \mathrm{ml}$ sodium hypochlorite solution addition aquades as much $180 \mathrm{ml}$ for 15 minutes. Rinsed seeds three times using aquades and soaked for 24 hours [13]. Germinated in petridish stored dark place for 3 days.

Rice seeds were planted in a $20 \mathrm{~cm}$ diameter bucket containing dry soil. Each bucket planted three seeds were then spared into one plant after 21 days. Fertilizer NPK 16-16-16 as much $6.25 \mathrm{~g} / 5 \mathrm{~kg}$ given at planting on each bucket. After 28 days the plant was given a drought treatment not giving irrigation to each bucket for 12 days of drought treatment.

Soil water content (SWC) is determined to weigh a soil sample the top, middle and bottom of the bucket to obtain fresh weight (FW) and drying in an oven at a temperature $80^{\circ} \mathrm{C}$ for $2 \times 24$ hours to get dry weight (DW). SWC obtained using the formula:

$$
S W C=\frac{F W-D W}{F W} \times 100 \%
$$


Relative water content (RWC) is measured taking 15 pieces of leaf samples size $0.5 \mathrm{~cm}$ using a cork borer. Leaf samples obtained weighed to get a fresh weight (FW), then do hydration for 24 hours to obtain a turgid weight (TW). The next sample in an oven at $80^{\circ} \mathrm{C}$ for $2 \times 24$ hours to obtain dry weight (DW). RWC can be calculated using the formula:

$$
R W C=\frac{F W-D W}{T W-D W} \times 100 \%
$$

Leaves microscopic preparations made with a transverse incision according to the method of paraffin with a mixture of n-butanol solution alcohol. Preparations slide observed under a light microscope with observation parameters include epidermis thickness, bulliform cells, and stomata size.

\section{Results and Discussion}

\subsection{Plant Water Status}

The plant's response to drought begins with a physiological response reducing water requirements in plants when there is a decrease in moisture soil water content (SWC). The lower water content in the soil, more energy plant needs to absorb water. The decrease SWC continued to occur until end treatment 12 days after drought treatment (Table 2). Based on results SWC percentage highest drought-stress treatment in rice varieties V14 (Randam Kaus) $11.58 \%$ and lowest V13 (Baroto) 9.40\%.

Decreasing SWC can lead to imbalance water flow in plants, resulting in water deficits and physiological disturbances in plant cells. In this condition, the potential groundwater is very low so that plants are unable to maintain turgor pressure even though water loss through transpiration stops [14].

Table 2. Average Percentage of SWC and RWC 12 days after drought treatment.

\begin{tabular}{ccccccc}
\hline \multirow{2}{*}{ Parameter } & \multirow{2}{*}{ Treatment } & \multicolumn{5}{c}{ Rice Varieties } \\
\cline { 3 - 7 } & & V2 & V10 & V12 & V13 & V14 \\
\hline \multirow{2}{*}{ MWC (\%) } & P0 & $66,34^{\mathrm{ab}}$ & $63,34^{\mathrm{ab}}$ & $68,39^{\mathrm{ab}}$ & $71,69^{\mathrm{b}}$ & $58,31^{\mathrm{a}}$ \\
& $\mathrm{P} 1$ & $11,24^{\mathrm{b}}$ & $10,64^{\mathrm{b}}$ & $10,60^{\mathrm{b}}$ & $9,40^{\mathrm{a}}$ & $11,58^{\mathrm{b}}$ \\
\hline \multirow{2}{*}{ RWC (\%) } & $\mathrm{P} 0$ & $52,55^{\mathrm{a}}$ & $53,65^{\mathrm{a}}$ & $61,55^{\mathrm{b}}$ & $63,40^{\mathrm{b}}$ & $55,25^{\mathrm{a}}$ \\
& $\mathrm{P} 1$ & $24,38^{\mathrm{a}}$ & $21,06^{\mathrm{a}}$ & $19,23^{\mathrm{a}}$ & $30,48^{\mathrm{a}}$ & $33,85^{\mathrm{a}}$ \\
\hline
\end{tabular}

Note: Numbers followed by the same score on the same row of each variety were not significantly different from the Duncan test at the level of $5 \%$. Treatment factors P0 (Control), P1 (Drought), Rice varieties V2 (Situbagendit), V10 (Indragiri), V12 (Sijunjuang), V13 (Baroto), V14 (Randam Kaus).

The reduction of soil water content (SWC) due to drought treatment led to a decrease in relative water content (RWC) leaves plants (Table 2). Treatment 12 days after drought plants experienced a decreased in RWC below 60\%. Rice varieties V13 (Baroto) have a higher RWC value compared to other rice varieties. This is suspected varieties V13 (Baroto) is able to use water more efficiently. The low-value RWC on rice varieties that suffered a drought in dry variety shows that a provisional response lowering the turgor in order to survive so that cells become smaller in 
size. Relative water content (RWC) leaf modifiers resistance drought-stress $[15 ; 16]$ because can describe water status and turgor pressure from leaf cells so that stomata close.

\subsection{Response Leaf Anatomy}

A leaf is important to plant organs because are the main place for photosynthesis [17]. The leaf organ consists of the epidermis as dermal tissue, mesophyll as basic tissue, and transport network. In the outer layer epidermal wall covered cuticle layer that covers leaf surface and between epidermal cells there are epidermal cell derivatives is stomata, trichomes, bulliform cells, silica cells, and cork cells [18; 19].

The anatomical response of leaves to environmental changes can be identified observing in the anatomical structure leaves given drought treatment. The observed anatomical structures leaf observed includes the lower surface bulliform cells, epidermal cells, and stomata size. Based on the results analysis, it appears that there is a decrease in size bulliform cells 12 days after drought is evident rice varieties V12 (Sijunjuang) which has a small bulliform cells with a length $1.76 \mu \mathrm{m}$ and width $1.11 \mu \mathrm{m}$ compared to V13 (Baroto) has a large bulliform cells with a length $3.43 \mu \mathrm{m}$ and width $3.64 \mu \mathrm{m}$ (Table 3 ).

Bulliform cells are easily influenced turgor pressures especially in closing movements and opening adult leaves in process winding leaves, due to their nature protecting tissues underneath so as not to suffer damage due to greater water loss [20].

Table 3. Measurement of leaf cells 12 days after drought treatment.

\begin{tabular}{lccccc}
\hline & \multicolumn{5}{c}{ Rice Varieties } \\
\cline { 2 - 6 } \multicolumn{1}{c}{ Leaf } & V2 & V10 & V12 & V13 & V14 \\
\cline { 2 - 6 } & & & & \\
\hline Bulliform & & & & \\
Cells & & & & & \\
$(\mu \mathrm{m})$ & & $1,66^{\mathrm{a}}$ & $1,76^{\mathrm{a}}$ & $3,43^{\mathrm{c}}$ & $2,86^{\mathrm{bc}}$ \\
Lenght & $2,25^{\mathrm{ab}}$ & $1,61^{\mathrm{ab}}$ & $1,11^{\mathrm{a}}$ & $3,64^{\mathrm{d}}$ & $2,51^{\mathrm{c}}$ \\
Width & $1,82^{\mathrm{b}}$ & & & & \\
\hline
\end{tabular}

Thickness

Cells

$(\mu \mathrm{m})$

\begin{tabular}{lccccr} 
Epidermis & $0,328^{\mathrm{ab}}$ & $0,306^{\mathrm{a}}$ & $0,290^{\mathrm{a}}$ & $0,463^{\mathrm{c}}$ & $0,406^{\mathrm{bc}}$ \\
\hline $\begin{array}{l}\text { Stomata } \\
(\mu \mathrm{m})\end{array}$ & & & & \\
Lenght & $2,69^{\mathrm{ab}}$ & $3,26^{\mathrm{bc}}$ & $3,60^{\mathrm{c}}$ & $1,82^{\mathrm{a}}$ & $2,50^{\mathrm{a}}$ \\
Width & $2,27^{\mathrm{a}}$ & $2,68^{\mathrm{a}}$ & $2,91^{\mathrm{a}}$ & $1,69^{\mathrm{a}}$ & $2,29^{\mathrm{a}}$ \\
Size $(\mathrm{LxW})$ & $4,84^{\mathrm{a}}$ & $6,93^{\mathrm{b}}$ & $8,29^{\mathrm{b}}$ & $2,44^{\mathrm{a}}$ & $4,54^{\mathrm{a}}$ \\
Total $(40 \times 10)$ & 10 & 13 & 11 & 8 & 10
\end{tabular}

Note: Numbers followed by the same score on the same row of each variety were not significantly different from the Duncan test at the level of 5\%. Treatment factors P1 (Drought), Rice varieties V2 (Situbagendit), V10 (Indragiri), V12 (Sijunjuang), V13 (Baroto), V14 (Randam Kaus). 
When the potential low water causes bulliform cells to be small size so that leaf water potential can be awake sweeping the area leaf thereby avoiding excessive evapotranspiration process. The results of microscopic observation apparently modified rice varieties bulliform cells V12 (Sijunjuang) has length and width small bulliform cells due to occurrence bulliform cells scraping as a modification anatomical structure in drought adaptation compared to V13 (Baroto) have large length and wide-sized bulliform cells, able to retain RWC leaves. This V13 (Baroto) has a modification anatomical structure related to adaptation developing bulliform cell so that it can withstand drought conditions pressing transpiration rate of water on the leaf surface (Figure 1). During excessive water shortages, bulliform cells along with mesophil cells conforming that allow leaves to become more easily folded or rolled [21].
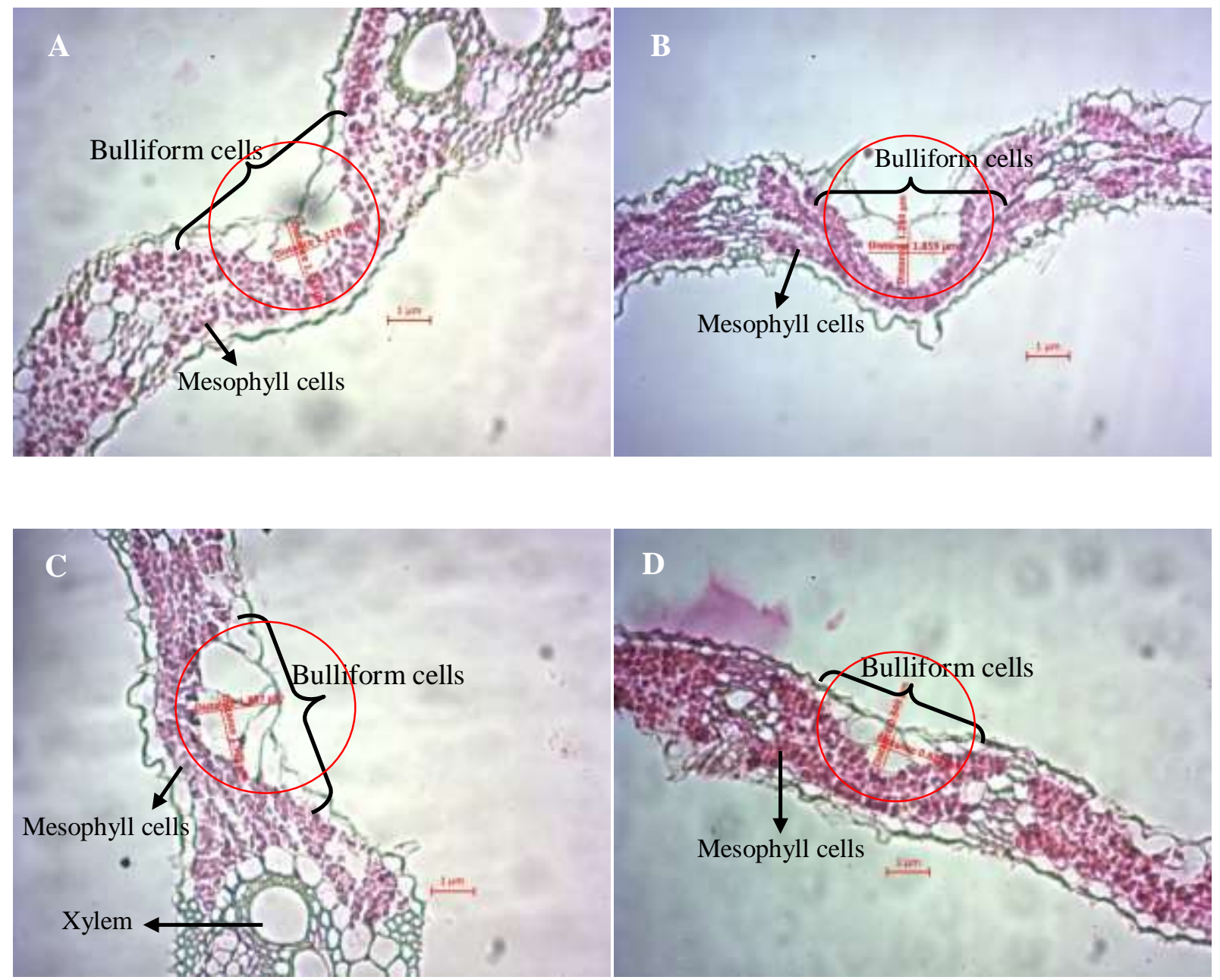


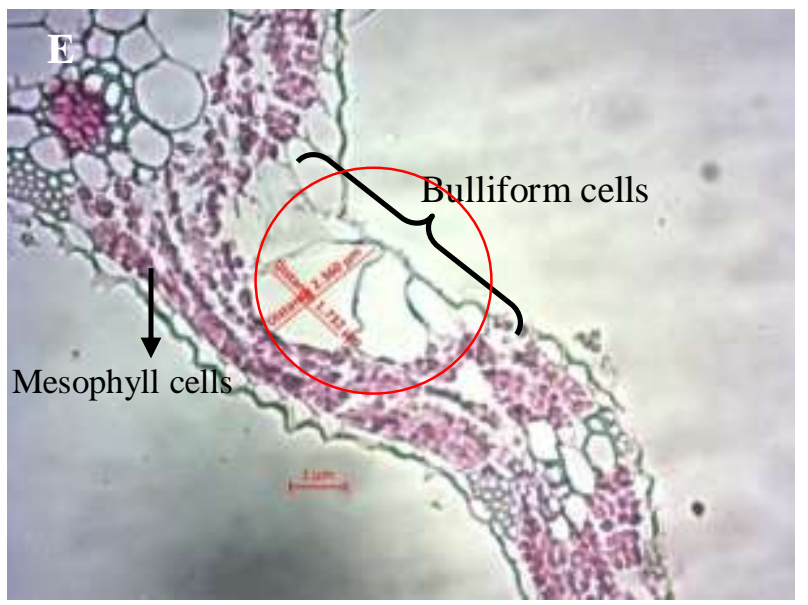

Figure 1. Modification bulliform cells 12 after days of drought treatment. (A) V2 (Situbagendit), (B) V10 (Indragiri), (C) V12 (Sijunjuang), (D) V13 (Baroto) and (E) V14 (Randam Kaus). Magnification 400x.

Drought condition for 12 days causes the rice to need protection so it affects thickness leaves. The changes occur in epidermis cells that have an enlarged thickness (Figure 2). The thickness epidermis cells is an important factor in resistance rice varieties to changing environment because epidermis cell is the outer tissue as protection of photosynthetic organs in leaves.

The microscopic observation epidermis leaves do not show changes in different cell structures. The results measurement epidermis cell rice varieties V13 (Baroto) have a thick epidermis highest $0.463 \mu \mathrm{m}$. Modification epidermis cell drought-bleeding condition will undergo thickening of epidermis wall in an effort to keep water content in inner cells of drought condition as a response to reduce transpiration and drought with reaction to form a defense increase thick epidermis.

Most photosynthesis took place in the mesophyll, located between the two layers of the epidermis with two layers can be distinguished. Mesophyll the top layer is a layer of dense shaped pole or milestones. This layer is called the mesophyll palisade and contains more than $80 \%$ of that is in the chloroplasts of leaves. The lower layer of mesophyll cells arranged in loose parenkim cells because the space between the cells more, this layer is called the mesophyll sponge. Much of these cells contain chloroplasts [22]. The presence of drought led to the density cell mesophyll palisade and smaller. It also reduces the air chamber intercellular on mesophyll sponges. 

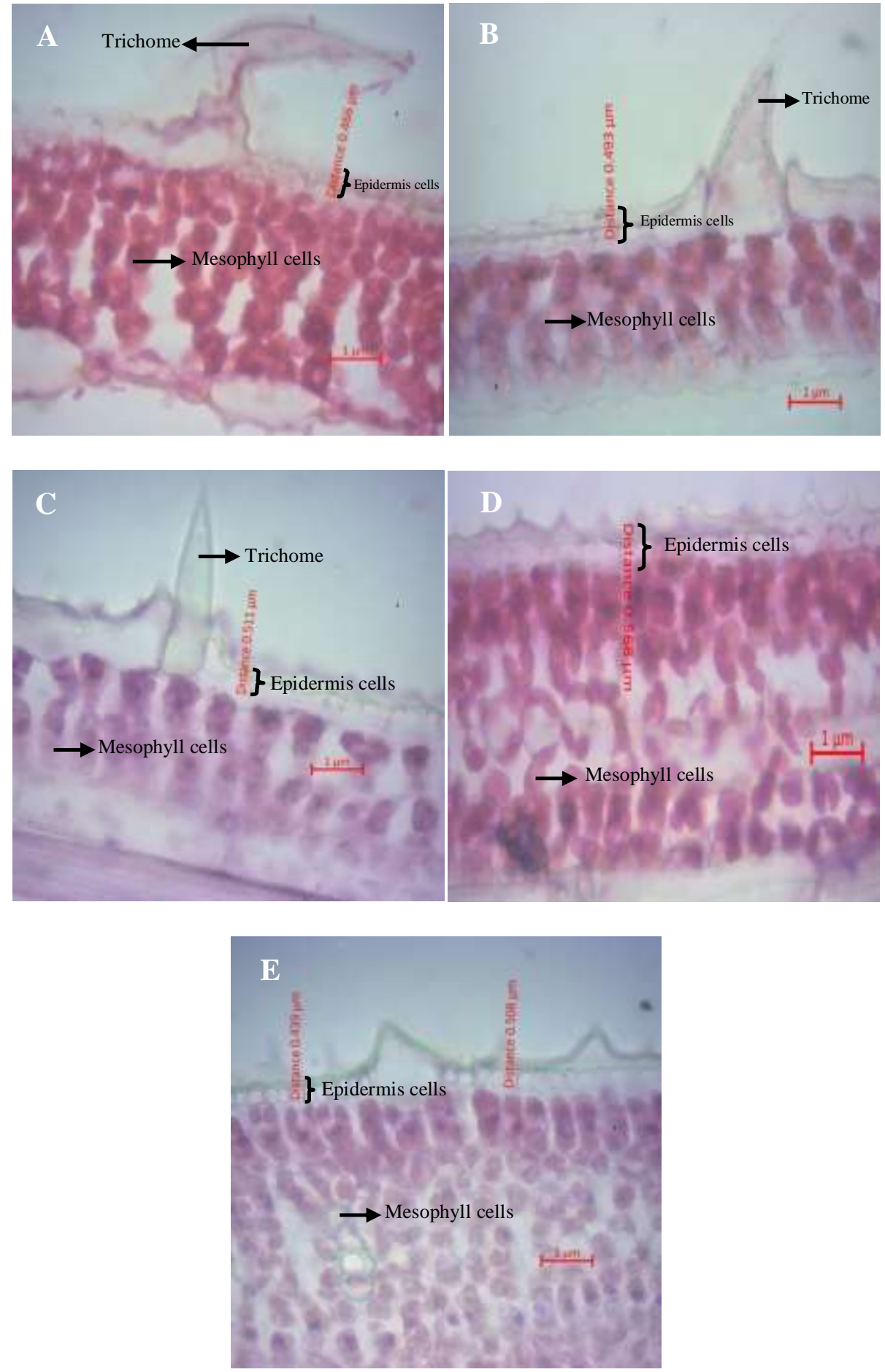

Figure 2. Modification epidermis cells 12 days after drought treatment. (A) V2 (Situbagendit), (B ) V10 (Indragiri), (C) V12 (Sijunjuang), (D) V13 Baroto and (E ) V14 (Randam Kaus). Magnification 1000x. 
The treatment for 12 days drought causes loss of turgidity cells, thereby affecting stability anatomical structure on rice varieties especially at stomata size (Table 3). Results microscopic anatomical analysis showed the occurrence of changes stomata arrangement which is located in an unaligned line due to drought-induced adaptation (Figure 3). Rice varieties that experience drought-based moisture can adapt to reduce stomata size which varies as water efficiency and drought tolerance. Stomata size and pore width relate to opening and closing stomata processes as gas exchanges and environmental change factor such as water status on each variety.
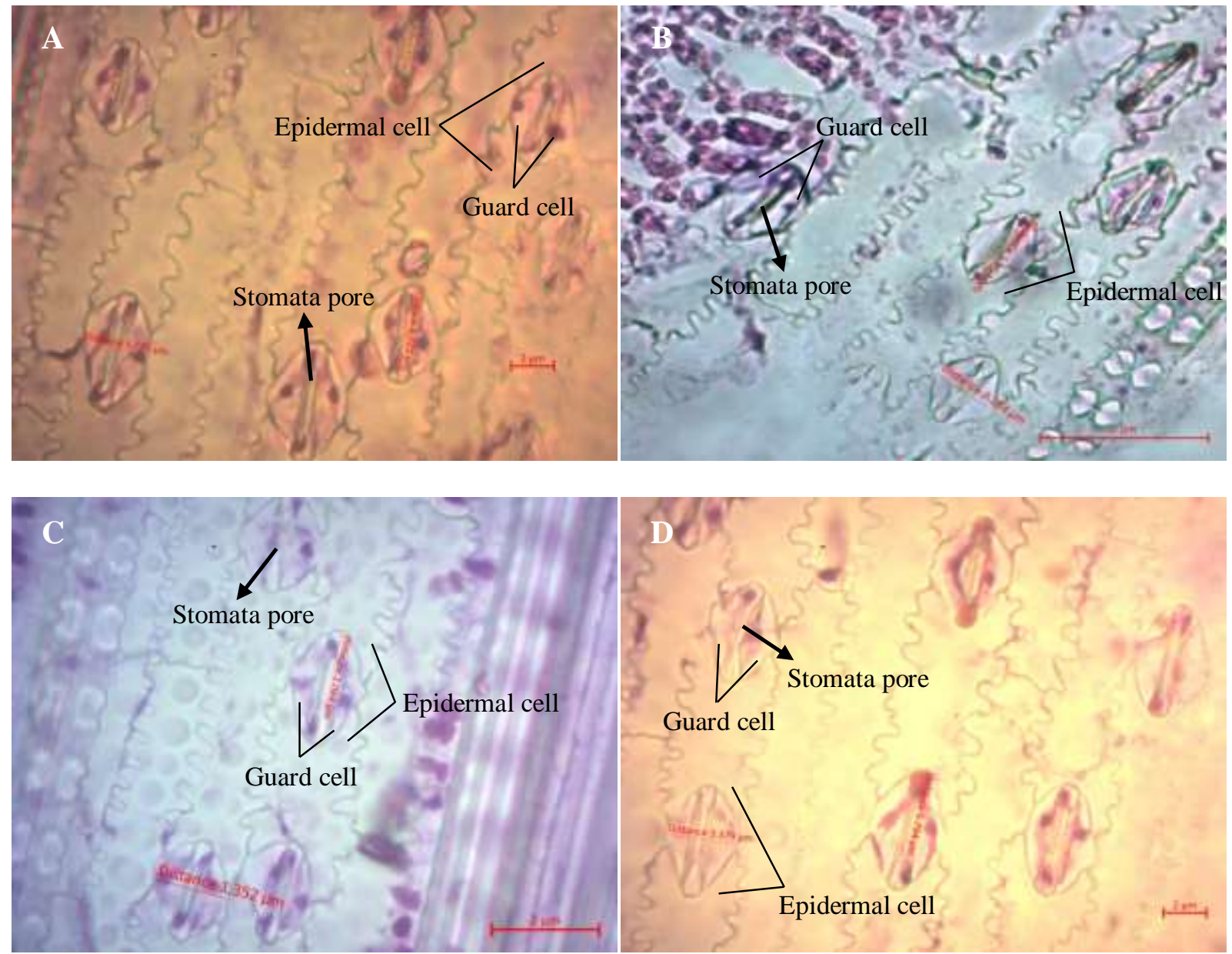


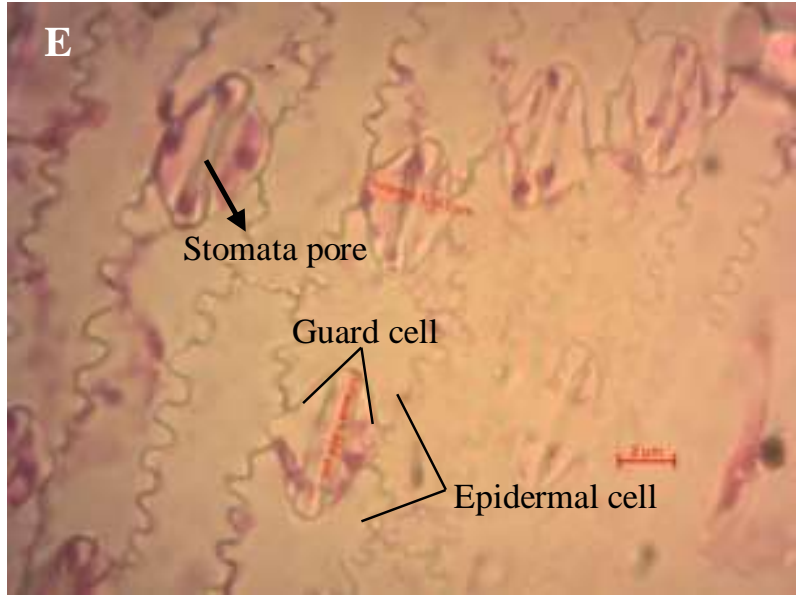

Figure 3. Stomata 12 days after drought treatment. (A) V2 (Situbagendit), (B ) V10 (Indragiri), (C) V12 (Sijunjuang), (D) V13 Baroto and (E ) V14 (Randam Kaus). Magnification 1000x.

Based on stomata size (Table 3) shows a significant difference between rice varieties that

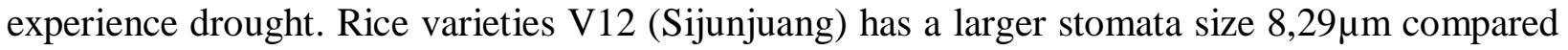
to other rice varieties. This tends to cause a plant to wither easily because of the transpiration rate increases due to large stomata size. Therefore, the larger stomata size tends to be more sensitive

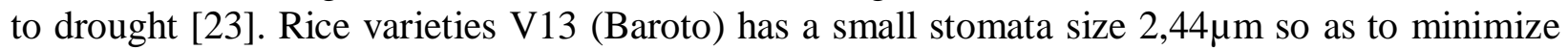
the use of water in condition drought. Occurrence this difference is suspected because there is a different change in turgor pressure on each cell rice varieties cover.

\section{Conclusion}

Leaf Anatomy of modifications to drought led to a decrease in the size of the bulliform cells due to scraping, increased the thickness of the wall of the cells of the epidermis, and a decrease in size with total stomatal in an effort to maintain the water potential of the leaves.

\section{References}

[1] Azhari, S., Violita. (2019). Identification of Drought Tolerance of West Sumatera Local Rice (Oryza sativa L.) at Germination Stage Using PEG 8000. Bio Sains. Vol 4 No 1 : 21 28.

[2] Azhari, S. (2019). Respon Perkecambahan Beberapa Varietas Padi (Oryza sativa L.) di Sumatera Barat pada Konsentrasi PEG 8000 yang berbeda. (Skripsi). FMIPA Universitas Negeri Padang. Padang.

[3] Banyo, Y.E., N.S. Ai, P. Siahaan, dan A.M. Tangapo. (2013). Konsentrasi Klorofil Daun Padi Pada Saat Kekurangan Air yang Diinduksikan Dengan Polietilen Glikol. Jurnal Ilmiah Sains 13(1):1-8.

[4] Castillo, E. G., T. P. Tuong, U. Singh, K. Inubushi, J. Padilla. (2006). Drought Response of Dry Seeded Rice to Water Stress Timing, N-Fertilizer Rates and Sources. Soil Sci. Plant Nutr. $52: 249-508$.

[5] Fahn, A. (1995). Anatomi Tumbuhan. Edisi ketiga. Yogyakarta: UGM Press. 
[6] Fontenelle, GB. (1994). Foliar Anatomy and Micro-Morphology of Eleven Species of Eugenia L. (Myrtaceae). Botanical Journal of the Linnean Society 115: 11 1-133.

[7] Hamim. (2007). Fisiologi Tumbuhan. Universitas Terbuka. Jakarta. 235 hal.

[8] Hamim. (2004). Underlying Drought Stress Effects on Plant: Inhibition of Photosynthesis. Hayati 11(4):164-169.

[9] Hidayat, E.B. (1995). Anatomi Tumbuhan Berbiji. Institut Teknologi Bandung. Bandung.

[10] Kim, G.T, S.Yano, T. Kozuk and H. Tsukaya. (2005). Photomorphogenesis of Leaves: Shade-Avoidance and Differentiation of Sun and Shade Leaves. Photochemical and Photobiological Science. 4:7 70-774.

[11] Longhi-Wagner H.M. (2001). Tribo Arundinelleae. In: Wanderley, M. G. L.; Shepherd, G. J. and Giulietti, A. M. Flora fanerogâmica do Estado de São Paulo, Poaceae. Fapesp Hucitec, São Paulo. pp. 119-123.

[12] Pessarakli, M. (2002). Handbook of Plant and Crop Physiology (2sd ed. revised and expanded). New York: Marcell Dekker.

[13] Quilambo, O.A. (2004). Proline Content, Water Retention Capability and Cell Membrane Integrity as Parameters for Drought Tolerance In Two Peanut Cultivars. South African Journal of Botany. 70:227-234.

[14] Rasaei, Behnoush., Mohammad Eghbal Ghobadi, Maryam Khas-Amiri, Mokhtar Ghobadi. (2013). Effect of Osmotic Potential on Germination and Seedling Characteristics of Soybean Seed. Intl J Agri Crop Sci. Vol., 5 (11), 1265-1268.

[15] Santoso, B. B. dan Hariyadi. (2008). Metode Pengukuran Luas Daun Jarak Pagar (Jatropha curcas L.). Magrobis Jurnal Ilmu-ilmu Pertanian 8(1): 17-22.

[16] Sopandie, D. (2014). Fisiologi Adaptasi Tanaman Terhadap Cekaman Abiotik pada Agroekosistem Tropika. Bogor: IPB Press.

[17] Stern W.L, Morris, Judd W.S. (1994). Anatomy of the Thick Leaves in Dendrobium section Rhizobium (Orchidaceace). Int. J. Plant Sci. 115 (6): 716-729.

[18] Tanaka, Y., Sano, T. M., Tamaoki, Nakajima, N., Kondo, N. and Hasezana, S. (2005). Ethylene Inhibits Abscisic Acid-Induced Stomatal Closure in Arabidopsis. Plant Physiology, 138, 2337-2343.

[19] Tang A.C, Kawamitsu Y, Kanechi M, Boyer J.S. (2002). Photosynthetic Oxygen Evolution at Low Water Potential in Leaf Discs Lacking an Epidermis. Ann Bot. 89:861-870.

[20] Terashima, I., S-1 Miyazawa., Y.T. Hanba. (2001). Why Are Sun Leaves Thicker than Shade Leaves?- Consideration Based on Analyses of $\mathrm{CO}_{2}$, Diffusion in the Leaf. Journal Plant Res. 114: 93-105.

[21] Violita. (2007). Komparasi Respon Fisiologi Tanaman Kedelai yang Mendapatkan Cekaman Kekeringan dan Perlakuan Herbisida Paraquat. (Tesis). Pascasarjana Institut Pertanian Bogor. Bogor.

[22] Woelaningsih, S. (2001). Struktur dan Perkembangan Tumbuhan II. Fakultas Biologi Universitas Gadjah Mada. Yogyakarta.

[23] Zou Liang-Ping, Sun Xue-Hui, Zhang Zhi-Guo, Liu Peng, Wu Jin-Xia, Tian Cai-Juan, Qiu Jin-Long, Lu Tie-Gang. (2011). Leaf Rolling Controlled by the Homeodomain Leucine Zipper Class IV Gene Roc5 in Rice. Plant Physiology. 156:1589-1602.

[24] Awasthi JP, Chandra T, Mishra S, Parmar S, Shaw BP, Nilawe PD, et al. Identification and characterization of drought responsive miRNAs in a drought tolerant upland rice cultivar KMJ 1-12-3. Plant physiology and biochemistry : PPB. 2019;137:62-74. 
[25] Qin G, Nguyen HM, Luu SN, Wang Y, Zhang Z. Construction of introgression lines of Oryza rufipogon and evaluation of important agronomic traits. TAG Theoretical and applied genetics Theoretische und angewandte Genetik. 2019;132(2):543-53.

[26] Islam MO, Kato H, Shima S, Tezuka D, Matsui H, Imai R. Functional identification of a rice trehalase gene involved in salt stress tolerance. Gene. 2019;685:42-9.

[27] Sengupta S, Mangu V, Sanchez L, Bedre R, Joshi R, Rajasekaran K, et al. An actindepolymerizing factor from the halophyte smooth cordgrass, Spartina alterniflora (SaADF2), is superior to its rice homolog (OsADF2) in conferring drought and salt tolerance when constitutively overexpressed in rice. Plant biotechnology journal. 2019;17(1):188-205. 